\title{
ANALISIS LEMBAR KERJA PESERTA DIDIK (LKPD) SEBAGAI BAHAN AJAR BIOLOGI
}

\author{
Ely Istiqomah ${ }^{1}$ \\ ${ }^{1}$ Institut Agama Islam Negeri Jember, Jl. Mataram No. 1 Mangli, Jember 68136, \\ Jawa Timur, Indonesia \\ E-mail: elyistiqomah7597@gmail.com
}

\begin{abstract}
This research aims to determine the utilization and suitability of the contents of Students Worksheets as a biology teaching material XI IPA class with the curriculum 2013 at SMAN 3 Jember year lesson 2018/2019. Utilization of Students Worksheets to determine the process of drafting SW, the implementation of biological learning using SW. The suitability of LKPD content is analyzed based on display, material, linguistic and question. This research is a qualitative descriptive research. Data analysis is done by calculating the percentage of students Worksheets conformity components. The results of this research for the students worksheet which is compiled suitable using various methods of learning. Results of conformity student worksheets with the curriculum 2013 class XI IPA at SMAN 3 Jember has a level of conformity is still less in accordance with the standards set by Permendikbud number 8 year 2016 unit that is the view section Includes the Skins section, the beginning of the book, the content, and the end gets $83.3 \%$. There are still two basic competencies that are not listed on the studente worksheet. The average linguistic section gets a value of $80 \%$. The question section gets an average value of $66.6 \%$.
\end{abstract}

Keyword: Student Worksheets, Teaching materials, Student Worksheet conformity, Curriculum 2013

\begin{abstract}
Abstrak : Penelitian ini bertujuan untuk mengetahui pemanfaatan dan kesesuaian isi Lembar Kerja Peserta Didik (LKPD) sebagai bahan ajar biologi kelas XI IPA menggunakan kurikulum 2013 di SMAN 3 Jember tahun pelajaran 2018/2019. Pemanfaatan LKPD untuk mengetahui proses penyusunan LKPD, pelaksanaan pembelajaran biologi menggunakan LKPD, dan evaluasi pembelajaran. Kesesuaian isi LKPD dianalisis berdasarkan tampilan, materi, kebahasaan dan soal. Penelitian ini merupakan penelitian kualitatif deskriptif. Analisis data dilakukan dengan menghitung persentase komponen kesesuaian LKPD. Hasil penelitian ini bahwa LKPD yang disusun dapat digunakan dengan berbagai metode pembelajaran. Hasil kesesuaian LKPD dengan kurikulum 2013 kelas XI IPA di SMAN 3 Jember memiliki tingkat kesesuaian masih kurang sesuai dengan standar yang ditetapkan oleh Permendikbud nomor 8 Tahun 2016 tentang buku yang digunakan oleh satuan pendidikan yaitu bagian tampilan meliputi bagian kulit, awal buku, isi, dan bagian akhir. Bagian penyajian yaitu $83,3 \%$. Bagian materi masih terdapat dua Kompetensi Dasar yang belum tercantum pada LKPD yaitu bab sistem reproduksi dan sistem imun. Bagian kebahasaan rata-rata 80\%. Bagian soal mendapatkan nilai rata-rata $66,6 \%$. Hal ini menunjukkan bahwa LKPD biologi kelas XI IPA di SMAN 3 Jember masih kurang baik dalam segi penyusunannya akan tetapi layak digunakan karena soal yang disusun guru mengajak siswa untuk berpikir kritis.
\end{abstract}

Kata Kunci: LKPD, Bahan Ajar, Kesesuaian LKPD, Kurikulum 2013

Lembaga Sekolah Menengah Atas Negeri 03 Jember termasuk sekolah yang diminati oleh siswa yang berdomisili Jember maupun dari luar kota Jember, dikarenakan memiliki keunggulan ekstrakurikuler dibidang kesenian. Kurikulum yang digunakan dalam proses pembelajaran yaitu kurikulum 2013. Proses pembelajaran biologi kelas XI IPA di sekolah ini menggunakan Lembar Kerja atau disebut juga dengan Lembar Kerja Peserta Didik (LKPD). LKPD tersebut disusun sendiri oleh guru biologi kelas XI dan digunakan dari tahun ketahun. 
LKPD disusun untuk mempermudah dan membantu guru dalam proses pembelajaran agar terjadi interaksi yang aktif antara siswa dan guru. Selain itu juga untuk meningkatkan aktifitas belajar siswa dalam meningkatkan prestasi belajar. Pembelajaran yang baik adalah ketika guru mampu memberikan pembelajaran yang inovatif sehingga tidak membosankan bagi peserta didik.

Kebiasaan siswa mengerjakan dengan mengambil jawaban dari internet, buku paket atau literatur lain disertai kurangnya pemahaman yang lebih mendalam dari guru maka dikhawatirkan terjadi miskonsepsi pada pemahaman siswa. Terlebih mereka malas untuk membaca buku dan lebih mengandalkan jawaban dari internet langsung. Oleh karena itu guru harus cermat, memiliki pengetahuan dan keterampilan yang memadai dalam menyusun LKPD, karena LKPD yang digunakan sebagai bahan ajar harus memenuhi kompetensi dasar, indikator, tujuan, materi dan evaluasi pencapaian pemahaman peserta didik.

Kurikulum 2013 menekankan pembelajaran dengan pendekatan saintifik, salah satunya dengan menggunakan Lembar Kerja Peserta Didik untuk proses belajar mengajar yang melibatkan keaktifan siswa pada proses pembelajaran. Lembar kerja yang digunakan bersifat kontekstual dan disesuaikan dengan kurikulum. Menurut Sani (2018) standar kompetensi lulusan kurikulum 2013 memiliki kriteria kemampuan lulusan yang mencakup aspek sikap, pengetahuan dan keterampilan. Implementasi kurikulum 2013 diharapkan mampu membuat siswa memiliki kompetensi sikap, pengetahuan dan keterampilan yang memadai. Kompetensi tersebut dapat dicapai dengan utuh dalam K-13 karena kurikulum ini menekankan penggunaan pendekatan ilmiah pada proses pembelajaran.

Realitas pendidikan di lapangan, masih banyak guru yang menggunakan bahan ajar konvensional yaitu bahan ajar yang tinggal pakai, tinggal beli, instan serta tanpa upaya merencanakan, menyiapkan dan menyusunnya sendiri. Dengan demikian resikonya sangat dimungkinkan jika bahan ajar yang mereka pakai itu tidak kontekstual, kurang menarik, monoton dan kurang sesuai dengan kebutuhan peserta didik. Bentuk bahan ajar konvensional biasanya seperti buku teks pelajaran yang diperjual belikan di toko-toko buku, buku sumbangan dari pemerintah, LKS yang dibeli dari para penyalur yang sering datang ke sekolah. Akan tetapi di SMAN 3 Jember guru telah memberikan inovasi dengan menyusun bahan ajar berupa LKPD untuk kepentingan proses pembelajaran biologi kelas XI IPA dengan tujuan siswa dapat dengan nyaman dan mudah dalam memahami suatu materi. Seorang guru dituntut kreativitasnya untuk mampu menyusun bahan ajar yang inovatif, menarik, kontekstual dan sesuai dengan tingkat kebutuhan peserta didik. Dengan kondisi pembelajaran yang menyenangkan secara otomatis dapat memicu terjadinya proses pembelajaran yang efektif. 
Oleh karena itu guru harus cermat, memiliki pengetahuan dan keterampilan yang memadai dalam menyusun LKPD, karena LKPD yang digunakan sebagai bahan ajar harus memenuhi kompetensi dasar, indikator, tujuan, materi dan evaluasi pencapaian pemahaman peserta didik. Hal tersebut seperti tertuang dalam Permendikbud nomor 8 Tahun 2016 pasal 6 yang berbunyi kelayakan isi, bahasa, penyajian, dan kegrafisan buku teks atau non teks pelajaran dinilai oleh BSNP. Menurut Prastowo (2015) menjelaskan bahwa lembar kegiatan siswa (student work sheet) merupakan lembaran-lembaran berisi tugas yang harus dikerjakan oleh peserta didik. Lembar kegiatan siswa biasanya berupa petunjuk atau langkah-langkah untuk menyelesaikan suatu tugas. Tugas tersebut harus jelas kompetensi dasar yang akan dicapai. Pembuatan bahan ajar harus disesuaikan dengan kebutuhan siswa. Unsur yang harus ada dalam penyusunan bahan ajar diantaranya petunjuk belajar, kompetensi yang akan dicapai, informasi pendukung, latihan-latihan atau tugas, petunjuk kerja atau lembar kerja dan evaluasi.

Bahan ajar merupakan segala bahan (baik informasi, alat, maupun teks) yang disusun secara sistematis, yang menampilkan sosok utuh dari kompetensi yang akan dikuasai siswa dan digunakan dalam proses pembelajaran dengan tujuan untuk perencanaan dan penelaahan implementasi pembelajaran. Oleh karenanya isi bahan ajar meliputi pengetahuan (fakta, konsep, prinsip dan prosedur), keterampilan dan sikap (nilai) (Prastowo, 2015). Kurikulum 2013 menekankan pembelajaran dengan pendekatan saintifik, salah satunya dengan menggunakan Lembar Kerja Peserta Didik untuk proses belajar mengajar yang dimana melibatkan keaktifan siswa pada proses pembelajaran. Lembar kerja yang digunakan bersifat kontekstual dan disesuaikan dengan kurikulum. Menurut Sani (2018) standar kompetensi lulusan kurikulum 2013 memiliki kriteria kemampuan lulusan yang mencakup aspek sikap, pengetahuan dan keterampilan. Implementasi kurikulum 2013 diharapkan mampu membuat siswa memiliki kompetensi sikap, pengetahuan dan keterampilan yang memadai.

Tujuan penelitian ini ada dua, yang pertama untuk mengetahui pemanfaatan Lembar Kerja Peserta Didik (LKPD) sebagai bahan ajar biologi kelas XI IPA di SMAN 3 Jember Tahun Pelajaran 2018/2019. Kedua untuk mengetahui kesesuaian isi Lembar Kerja Peserta Didik (LKPD) sebagai bahan ajar biologi kelas XI IPA dengan kurikulum 2013 di SMAN 3 Jember Tahun Pelajaran 2018/2019. Penelitian ini bermanfaat untuk guru maupun lembaga sekolah yang akan menyusun bahan ajar sendiri berupa LKPD. Penyusunan LKPD disesuaikan dengan kurikulum dan disesuaikan dengan kebutuhan peserta didik.

Urgensi diadakannya penelitian ini guna mengetahui sejauh mana efektifitas penggunaan LKPD biologi yang disusun sendiri oleh guru. LKPD digunakan dalam pembelajaran dari tahun ke tahun semenjak diberlakukannya kurikulum 2013 oleh Kementrian Pen- 
didikan dan Kebudayaan. Untuk mengetahui LKPD yang disusun seyogyanya sudah disesuaikan dengan peraturan Kementrian Pendidikan dan Kebudayaan. Karena sudah disebutkan pada Peraturan Menteri Pendidikan dan Kebudayaan Nomor 8 Tahun 2016 tentang buku yang digunakan oleh satuan pendidikan. Berhubung di SMAN 3 jember guru sudah menyusun bahan ajar berupa LKPD secara mandiri maka perlunya untuk dianalisis isinya. Oleh karenanya guru diharapkan mampu menyusun bahan ajar yang disesuaikan dengan peraturan yang sudah ada.

Dalam penelitian yang ditulis oleh Siti Maryam dalam Jurnal pendidikan Matematika dan Sains Edisi 1 Tahun Ke-1 2013 yang berjudul Analisis Isi Lembar Kegiatan Siswa (LKS) Biologi SMA yang digunakan di Kota Yogyakarta. Penelitian ini bertujuan untuk mengetahui indeks keterlibatan siswa dalam proses sains yang dikembangkan dalam LKS Biologi SMA, kesesuaian antara fenomena biologi yang diamati dengan konsep yang akan dicapai (content Analysis). Hasil dari penelitiannya bahwa indeks keterlibatan siswa dalam LKS yang berasal dari penerbit lebih tinggi dibandingkan LKS buatan guru. Hampir semua LKS menunjukkan kurang sesuai antara fenomena yang didapat dengan konsep biologi yang diperoleh. Hampir semua LKS arahan diskusinya kurang runtut. Dalam jurnal Pelita pendidikan Vol. 6 No.2 Tahun 2017 pISSN: 2338 -3003 eISSN: 2502 -3217 yang telah ditulis oleh Nurul Azmi yang berjudul Analisis Kesesuaian Lembar Kerja siswa (LKS) Biologi Kelas X yang Digunakan MAN Rantau Prapat Kabupaten Labuhan Batu. Penelitian yang dilakukan pada tahun 2017 yang bertujuan untuk mengetahui kelayakan lembar kerja siswa (LKS) kelas X yang digunakan di Rantau prapat berdasarkan isi, konstruksi, teknis penyajian dan kegrafikan. Hasil penelitian ini LKS yang digunakan dikelas X MAN Rantau Prapat memiliki tingkat kesesuaian yang tinggi dan sesuai dengan standar isi, teknis, kontribusi dan kegrafikan yang ditetapkan BSNP. Perbedaan penelitian terdahulu dengan penelitian ini yaitu lokasi penelitian dan tujuan penelitian. Tujuan penelitiannya untuk mengukur indeks keterlibatan siswa dalam proses sains yang dikembangkan dalam LKS Biologi SMA, kesesuaian antara fenomena biologi yang diamati dengan konsep yang akan dicapai (content Analysis).

\section{METODE}

Penelitian ini dilakukan di lembaga SMAN 3 Jember pada bulan April 2019 sampai Juli 2019. Informan pada penelitian ini adalah guru biologi kelas XI IPA, siswa kelas XI IPA, dan LKPD. Penentuan subyek ialah dengan purposive. Jenis penelitian ini adalah kualitatif deskriptif. Pengumpulan data dilakukan melalui observasi, wawancara dan dokumentasi. Ada dua jenis data pada penelitian ini yaitu data primer dan data sekunder. Data primer diperoleh 
melalui wawancara dengan informan yang dijadikan sampel penelitian. Informan yang diambil sebanyak empat orang yaitu satu orang guru biologi kelas XI IPA dan tiga siswa. Pengambilan informan menggunakan purposive sampling ialah penentuan informan dengan pertimbangan tertentu yang diyakini informan tersebut memahami data-data yang akan diperlukan oleh peneliti (Sugiyono, 2017; Satori, 2014). Sehingga peneliti mengambil tiga siswa kelas XI IPA secara random dari beberapa kelas dan satu guru biologi yang telah menyusun LKPD tersebut. Sedangkan data sekunder diperoleh dari LKPD biologi kelas XI IPA semester ganjil dan semester genap Tahun ajaran 2018/2019. LKPD dianalisis disesuaikan dengan standar Peraturan Menteri Pendidikan dan Kebudayaan Republik Indonesia nomor 8 Tahun 2016 tentang buku yang digunakan oleh satuan pendidikan yang tercantum pada pasal 3 tentang kriteria buku teks pelajaran dan buku non teks pelajaran.

Analisis LKPD meliputi empat aspek bagian yaitu aspek tampilan, aspek kebahasaan, aspek materi dan aspek soal. Analisis data menggunakan dua metode yang berbeda. Untuk rumusan masalah yang kesatu menggunakan analisis data menurut Miles, Huberman dan Saldana (2014). Keabsahan data menggunakan triangulasi teknik dan triangulasi sumber. Rumusan masalah yang kedua menggunakan rumus persentase dengan menggunakan daftar checklist. Selanjutnya nilai kesesuaian isi LKPD dihitung dengan menggunakan rumus dibawah ini (Sudjana, 2017):

$$
\dot{\mathbf{X}}(\text { Presentase kesesuaian LKPD })=\frac{\boldsymbol{\Sigma} \mathbf{X}}{\mathbf{N}} \times \mathbf{1 0 0 \%}
$$

Keterangan:

$$
\begin{array}{ll}
\dot{\mathbf{X}} & =\text { presentase kesesuaian } \\
\text { LKPD } \Sigma \mathbf{X} & =\text { jumlah Peryataan yang sesuai } \\
\mathbf{N} & =\text { banyaknya pernyataan }
\end{array}
$$

Hasil perhitungan dimasukkan dalam tabel persentase sesuai dengan kriteria yang telah ditetapkan. Dasar yang digunakan untuk menilai kesesuaian isi LKPD biologi dapat dilihat pada Tabel 1. 
Tabel 1. Kategori Presentase Kesesuaian LK

\begin{tabular}{cc}
\hline Presentase kesesuaian & Kategori \\
\hline $81 \%-100 \%$ & Sangat baik \\
\hline $61 \%-80 \%$ & Baik \\
\hline $41 \%-60 \%$ & Cukup \\
\hline $21 \%-40 \%$ & Kurang \\
\hline $0<20 \%$ & Sangat kurang \\
\hline
\end{tabular}

Sumber: Arikunto, 2009

Untuk mengetahui kesesuaian isi LKPD biologi terlebih dahulu disesuaikan dengan Permendikbud no 8 Tahun 2016 tentang Buku yang digunakan oleh satuan Pendidikan. Kemudian dimasukkan kedalam rumus. Hasil dari perolehan penghitungan nantinya dicocokkan dengan tabel diatas untuk mengetahui presentase kelayakan LKPD yang sudah disusun.

\section{HASIL}

\section{Pemanfaatan Lembar Kerja Peserta Didik (LKPD)}

Pembelajaran biologi kelas XI IPA di SMAN 3 Jember memakai LKPD yang telah dilakukan guru sejak berlakunya kurikulum 2013. LKPD biologi ini disusun sendiri oleh guru biologi kelas XI IPA. Penyususnan LKPD disesuaikan dengan prota, prosem, silabus, RPP, buku kerja guru yang telah diterbitkan oleh kemendikbud serta dari beberapa sumber litarur yang juga disesuiakan dengan lingkungan sekolah. Berdasarkan hasil wawancara dengan bu Yuswita selaku guru biologi yang telah menyusun LKPD mengatakan bahwa "Tujuan dari penyusunan LKPD ini agar siswa dapat berfikir kritis, aktif dalam pembelajaran, dan siswa memiliki rasa ingin tahunya karena pada LKPD materi yang dicantumkan hanya tertulis tujuan Pembelajaran, alat dan bahan, langkah kerja, serta soalsoal. Oleh karenanya materi ini diambil dari tujuan pembelajaran karena tujuan pembelajaran mencakup kompetensi inti dan kompetensi dasar. Sehingga siswa dapat belajar mencari materi yang sesuai dari beberapa sumber bacaan. LKPD biologi ini dapat diterapkan dengan berbagai macam metode atau strategi pembelajaran."

Susunan LKPD biologi dimulai dari cover (bagian depan) sampai bagian isi atau materi pada setiap sub bab. Sedangkan bagian belakang buku langsung memakai kertas buffallo yang kemudian dijilid menjadi LKPD semester ganjil dan LKPD semester genap Tahun Pelajaran 2018/2019. Setelah bagian sampul langsung berisi materi setiap sub bab. Materi dalam LKPD ini disusun dengan rancangan membuka peluang kepada siswa untuk mencari informasi yang berhubungan dengan kemajuan teknologi yang berkembang saat ini. Sehingga siswa bisa saling membagi informasi pengetahuan kepada guru dan teman sebayanya tentang tekonologi-tekonologi terkini yang berkaitan dengan biologi. Tujuan 
awal penyusunan LKPD untuk memenuhi aspek pembelajaran kebutuhan siswa aspek kognitif, afektif dan psikomotorik. Untuk mengetehui sejauh mana siswa memahami materi maka aspek kognitif dilihat dari soal-soal yang telah disajikan.

Adapun untuk mengetahui sikap siswa dalam setiap pembelajaran maka untuk menilai aspek afektif, guru biasanya menilai dari penilaian yang ada pada RPP. Sedangkan untuk mengetahui aspek keterampilan siswa dalam proses pembelajaran maka untuk menilainya guru mencantumkan lembar kerja berupa eksperimen. Lembar kerja eksperimen dapat dijumpai pada setiap bab. Karena setiap satu bab dirancang terdapat praktikum, dari praktikum itu guru dapat mengetahui kemampuan psikomotorik siswa. Aspek kognitif dapat dilihat juga pada Soal-soal yang ada di lembar kerja. Soal-soal tersebut disusun oleh guru secara rata berdasarkan Permendikbud No 22 Tahun 2016 mulai dari mengingat, memahami, menerapkan, menganalisis, mengevaluasi dan mencipta. Karena soal tersebut mendorong siswa untuk dapat berpikir kritis sehingga membuat siswa untuk menggali informasi yang lebih mendalam. Soal disusun acak pada LKPD mulai dari C1 (mengingat), C2 (memahami), C3 (menerapkan), C4 (menganalisis), dan C5 (mengevaluasi). Sedangkan untuk C6 (mencipta) diberikan ketika siswa remidi maka siswa akan mengerjakan lembar pengayaan yang diantaranya berisi soal C6. Soal yang terdapat dalam LKPD semuanya berbentuk uraian.

LKPD biologi ini selalu digunakan ketika proses pembelajaran di kelas maupun di dalam ruangan laboratorium. Ketika proses pembelajaran guru selalu menggunkaan metode pembelajaran yang berbeda dengan tujuan siswa tidak bosan dengan metode dan materi yang diberikan oleh guru. Metode yang sering dipakai selain ceramah ialah diskusi, presentasi, tanya jawab, praktikum, dan role playing. Adapun urutan isi LKPD biologi kelas XI IPA ialah judul sub bab Lembar Kerja, tujuan pembelajaran, alat dan bahan, langkah kerja, gambar, tabel hasil pengamatan, dan daftar soal. Untuk materi menyesuaikan dengan isi tujuan pembelajaran yang disesuaikan dengan kompetensi inti dan kompetensi dasar kurikulum 2013. Siswa kelas XI IPA merasa senang ketika pembelajaran biologi dengan menggunakan LKPD ini dikarenakan dapat melatih siswa untuk kreatif, disiplin dalam mengerjakan tugas dan membuat laporan dengan tepat waktu, dan melatih siswa untuk berpikir kritis. Selain mendapatkan teori siswa juga mendapatkan pengaplikasian dari teori tersebut.

Guru telah menyedikan rubrik penilaian untuk pelaksanaan evaluasi pembelajaran menggunakan LKPD biologi. Rubrik penilaian diantranya yaitu rubrik penilaian praktikum, rubrik penilaian laporan, dan rubrik penilaian sikap. Rubrik penilaian sikap 
menggunakan observasi meliputi penilaian santun, sikap tanggung jawab, sikap toleransi, sikap percaya diri, sikap jujur, sikap gotong royong, sikap spiritual dan penilaian sikap teman sebaya. Untuk penilaian aspek psikomotorik atau keterampilan maka menggunakan rubrik penilaian projek, dan rubrik penilaian praktikum. Untuk penulisan laporan disesuaikan dengan rubrik yang sudah ada. Jika lengkap dan sesuai maka diberi nilai 3, jika kurang diberi nilai 2, jika tidak mengerjakan diberi nilai 0 . Untuk penilaian aspek kognitif atau pengetahuan sudah tercantum pada LKPD yaitu berupa soal uraian.

\section{Analisis Lembar Kerja Peserta Didik (LKPD)}

Dokumen LKPD biologi yang dianalisis meliputi dari tampilan atau penyajian, materi, soal dan kebahasaan yang disesuaikan dengan aturan BSNP berdasarkan Peraturan Menteri Pendidikan dan Kebudayaan Republik Indonesia nomor 8 Tahun 2016.

\section{a. Analisis Berdasarkan Tampilan}

Bagian tampilan atau penyajian LKPD yang dianalisis yaitu bagian kulit buku, bagian awal buku, teknik penyajian, dan bagian akhir. Bagian kulit buku yang dianlisis yaitu kulit depan buku, kulit belakang buku, dan punggung buku. Sedangkan bagian awal buku yang dianlisis ialah halaman judul, halaman penerbitan, kata pengantar, daftar isi, daftar gambar, dan halaman tabel. Teknik penyajian yang dianalisis meliputi konsistensi sistematika sajian dalam bab, penomoran halaman, keruntutan penyajian dengan kompetensi inti dan kompetensi dasar, penyajian gambar dalam setiap bab, dan bahasa yang mudah dimengerti. Analisis terakhir bagian akhir buku yaitu glosarium, dan daftar pustaka. Hasil analisis dapat dilihat pada tabel berikut:

\section{Tabel 2. Tabel Analisis Bagian Tampilan LKPD}

\begin{tabular}{|c|c|c|}
\hline No & Bagian yang dianalisis & Nilai \\
\hline 1. & Kulit buku & $66,6 \%$ \\
\hline 2. & Awal buku & $0 \%$ \\
\hline 3. & Penyajian isi LKPD & $83,3 \%$ \\
\hline 4. & Akhir buku & $0 \%$ \\
\hline
\end{tabular}

Nilai pada tabel tersebut diperoleh dengan cara checklist terlebih dahulu, setelah disesuaikan dengan lembar ceklist maka dimasukkan kedalam rumus. Dari tabel diatas dapat diketahui bahwa persentase kesesuaian bagian tampilan LKPD yang tertinggi ialah pada bagian penyajian yaitu 83,3. Persentase tertinggi kedua yaitu bagian kulit buku yaitu 66,6\% yang artinya pada bagian ini kulit buku masuk kategori baik. Sedangkan bagian awal buku dan akhir buku mendapatkan nilai sebesar 0\%, nilai terse- 
but menunjukkan bahwa pada bagian awal dan akhir buku masuk kategori sangat kurang. Karena pada bagian tersebut tidak ada pada LKPD biologi.

\section{b. Analisis Berdasarkan Materi}

Materi biologi kelas XI SMA terdapat sebelas bab, dimulai kompetensi dasar 3.1, 4.1 sampai 3.14 dan 4.14. Materi yang terdapat pada LKPD semester ganjil dan genap tidak dicantumkan secara jelas, guru hanya mencantumkan tujuan pembelajaran. Jadi untuk menganalisis bagian materi disesuaikan dengan kompetensi inti dan kompetensi dasar kurikulum 2013. Analisis pada bagian materi ini menggunakan analisis deskriptif. Untuk menganalisis materi setiap sub bab dilihat pada tujuan yang tercantum dalam LKPD kemudian disesuaikan dengan kompetensi inti dan kompetensi dasar. Terdapat dua kompetensi dasar yang masih belum tercantumkan dengan baik di LKPD yaitu KD 4.13 bab sistem reproduksi dan KD 4.14 bab sistem imun.

\section{c. Analisis Berdasarkan Kebahasaan}

Adapun yang dianalisis bagian kebahasaan meliputi tata urutan pelajaran, kesalahan penulisan, struktur kalimat yang jelas, mendorong siswa untuk berpikir kritis, dan kebenaran penulisan nama ilmiah. Maksud dari tata urutan pelajaran ialah lembar kerja disusun urut sesuai bab yang tercantum pada peraturan pemerintah No 37 Tahun 2018 tentang kompetensi inti dan kompetensi dasar, urut sesuai tampilan lembar kerja mulai awal sampai akhir. Kesalahan penulisan meliputi kurangnya tanda baca, kurang huruf, salah penulisan penomoran pada setiap sub bab, menggunakan kata baku. Mendorong siswa berfikir kritis maksudnya ialah terdapat soal pada setiap sub bab untuk mengajak siswa berfikir kritis. Kebenaran penulisan naman ilmiah disesuaikan dengan binominal nomenklatur.

Adapun hasil analisis kebahasaan dapat dilihat pada tabel berikut:

Tabel 3. Tabel Analisis Bagian Kebahasaan

Jumlah

Aspek Penilaian

$\begin{array}{llllll}\text { No Bab } & \text { Tata uru- } & \text { Struktur } & \text { Kesalahan } & \text { Mendo } & \text { Kebenaran } \\ & \text { tan pela- } & \text { kalimat } & \text { penulisan } & \text { rong ber- } & \text { penulisan ka- } \\ & \text { jaran } & \text { yang jelas } & \text { pikir kritis } & \text { ta ilmiah }\end{array}$

\section{Lembar kerja Peserta Didik (LKPD) Semester Ganjil}

\begin{tabular}{llllllll}
\hline 1. & sel & $\sqrt{ }$ & $\sqrt{ }$ & $\mathrm{x}$ & $\sqrt{ }$ & $\sqrt{ }$ & $80 \%$ \\
\hline
\end{tabular}




\begin{tabular}{llllllll} 
2. $\begin{array}{llllll}\text { Jaringan Tum- } \\
\text { buhan }\end{array}$ & $\sqrt{ }$ & $\sqrt{ }$ & $\sqrt{ }$ & $\sqrt{ }$ & $\mathrm{x}$ & $80 \%$ \\
\hline 3. & $\begin{array}{l}\text { Jaringan He- } \\
\text { wan }\end{array}$ & $\sqrt{ }$ & $\sqrt{ }$ & $\mathrm{x}$ & $\sqrt{ }$ & $\mathrm{x}$ & $60 \%$ \\
\hline 4. & $\begin{array}{l}\text { Sistem } \\
\text { Gerak }\end{array}$ & $\sqrt{ }$ & $\sqrt{ }$ & $\sqrt{ }$ & $\sqrt{ }$ & $\mathrm{x}$ & $80 \%$ \\
\hline 5. & Sistem Sirkulasi & $\sqrt{ }$ & $\sqrt{ }$ & $\sqrt{ }$ & $\sqrt{ }$ & $\sqrt{ }$ & $100 \%$ \\
\hline 6. & $\begin{array}{l}\text { Sistem } \\
\text { Pencernaan }\end{array}$ & $\sqrt{ }$ & $\sqrt{ }$ & $\sqrt{ }$ & $\sqrt{ }$ & $\mathrm{x}$ & $80 \%$
\end{tabular}

\section{Lembar kerja Peserta Didik (LKPD) Semester Genap}

\begin{tabular}{llllllll}
\hline 1. & Sistem & $\sqrt{ }$ & $\sqrt{ }$ & $\mathrm{x}$ & $\sqrt{ }$ & $\sqrt{ }$ & $80 \%$ \\
& Respirasi & & & & & & \\
\hline 2. & Sistem Ekskre- & $\sqrt{ }$ & $\sqrt{ }$ & $\mathrm{x}$ & $\sqrt{ }$ & $\sqrt{ }$ & $80 \%$ \\
& si & & & & & & \\
\hline 3. & Sistem Regu- & $\sqrt{ }$ & $\sqrt{ }$ & $\mathrm{x}$ & $\sqrt{ }$ & $\sqrt{ }$ & $80 \%$ \\
& lasi & & & & & & \\
\hline 4. & Sistem & $\sqrt{ }$ & $\sqrt{ }$ & $\mathrm{x}$ & $\sqrt{ }$ & $\sqrt{ }$ & $80 \%$ \\
& Reproduksi & & & & & & \\
\hline 5. & Sistem Imun & $\mathrm{x}$ & $\sqrt{ }$ & $\mathrm{x}$ & $\sqrt{ }$ & $\sqrt{ }$ & $60 \%$ \\
\hline
\end{tabular}

Dibandingkan dengan LKPD semester ganjil maka LKPD semester genap nilainya hampir sama. Penilaian lembar kerja peserta didik semester genap rata-rata mendapatkan nilai persentase pada setiap bab ialah $80 \%$. Pada bab sistem respirasi, sistem Ekskresi, sistem saraf dan sistem reproduksi termasuk kedalam kategori baik karena mendapatkan nilai $80 \%$. Akan tetapi pada bab sistem imun mendapatkan nilai persentase $60 \%$, sehingga dapat diketahui pada bab ini mendapatkan nilai terendah dan masuk kedalam katergori cukup.

\section{d. Analisis Berdasarkan Soal}

Anilisis isi LKPD berdasarkan soal yang terdapat pada LKPD disamaratakan berdasarkan C1 (mengingat), C2 (memahami), C3 (menerapkan), C4 (menganalisis), C5 (mengevaluasi), C6 (mencipta). Berdasarkan hasil analisis diperoleh bahwa setiap sub bab terdapat jenis soal yang berbeda-beda. Pada bab pertama yaitu sel yang mendapatkan nilai tertinggi ialah 66,6\% yang terdapat pada sub bab lembar kerja 1.1, 
sub bab 1.2, dan sub bab 1.5. Pada bab dua nilai tertinggi ialah 83,3\% yaitu pada lembar kerja sub bab 2.1 dan sub bab 2.3. Adapun nilai tertinggi pada bab tiga ialah 66,6\% yaitu di LK 3.1. Pada bab empat nilai tertinggi ialah 83,3\% yang terdapat pada LK 4.1. sedangkan pada bab lima dan bab enam rata-rata nilainya sama yaitu 66,6\%.

Berdasarkan hasil analisis untuk LKPD semester genap yang terdapat lima bab. Bab sistem respirasi nilai tertinggi ialah 83,3\% yang terdapat pada lembar kerja 7.2 berupa eksperimen dengan soal C1, C2, C3, C4 dan C5. Nilai tertinggi pada sistem ekskresi ialah 83,3\% yang terdapat di lembar kerja 8.2 yang berupa non eksperimen. Sub bab Lembar kerja 8.2 soalnya dimulai dari C1, C2, C3, C4 dan C5. Sedangkan pada sistem saraf terdapat tujuh sub bab lembar kerja. Pada setiap sub bab lembar kerja mendapatkan nilai yang hampir sama yaitu $66,6 \%, 50 \%$ dan 33,3\%. Nilai tertinggi pada sistem reproduksi ialah $83,3 \%$ yang terdapat pada lembar kerja 10.4 yang berupa non eksperimen. Bab sistem imun mendapatkan nilai 83,3\% yang terdapat di lembar kerja 11.1 yang berupa LK eksperimen. Soal pada sub bab Lembar Kerja 11.1 mulai dari C1, C2, C3, C4 dan C5.

\section{PEMBAHASAN}

Berdasarkan hasil observasi, wawancara dan dokumentasi guru sebagai pendidik, fasilitator serta motivator untuk siswanya telah menyusun bahan ajar sendiri berupa LKPD biologi untuk kelas XI IPA. Adanya LKPD tersebut diharapkan sesuai dengan tujuan sekolah yaitu menyelenggarakan proses pembelajaran yang aktif, kreatif dan inofatif. Menurut guru sebagai penyusun LKPD biologi ini selain sebagai pedoman bahan ajar, siswa dapat belajar dengan mandiri, siswa dapat belajar dengan aktif dan memunculkan ide kreatif dalam proses pembelajaran. Hal ini sesuai dengan teori yang dipaparkan oleh Prastowo (2015) bahwa manfaat atau kegunaan bahan ajar dibedakan menjadi dua macam, yaitu kegunaan bagi guru dan kegunaan bagi peserta didik. Kegunaan bagi guru ialah guru akan memiliki bahan ajar yang dapat membantu dalam pelaksanaan kegiatan pembelajaran. kegunaan bagi siswa ialah kegiatan pembelajaran menjadi lebih menarik, siswa lebih banyak mendapatkan kesempatan untuk belajar secara mandiri dengan bimbingan guru dan siswa mendapatkan kemudahan dalam mempelajari setiap kompetensi yang harus dikuasainya.

Tujuan dari penyusunan LKPD juga sesuai dengan yang dipaparkan oleh Nurdin (2016) bahwa tujuan lembar kerja siswa yaitu mengaktifkan siswa dalam proses kegiatan pembelajaran, membantu siswa mengembangkan konsep, melatih siswa untuk menemukan dan mengembangkan keterampilan proses, sebagai pedoman guru dan siswa dalam melaksanakan 
proses kegiatan pembelajaran, membantu siswa dalam memperoleh catatan materi yang dipelajari melalui kegiatan pembelajaran, serta membantu siswa dalam memperoleh informasi tentang konsep yang dipelajari melalui proses kegiatan pembelajaran dan sistematis.

LKPD biologi yang telah disusun ini dikategorikan sebagai bahan ajar cetak, karena digunakan oleh guru sebagai pedoman dalam pelaksanaan pembelajaran di kelas maupun di luar kelas. Hal ini selaras dengan teori yang telah ditulis oleh Majid (2011) bahwa kriteria yang menjadi acuan dalam membuat klasifikasi adalah berdasarkan bentuknya, cara kerjanya, dan sifatnya. Menurut bentuknya bahan ajar dibedakan menjadi empat macam yaitu bahan cetak, bahan ajar audio, bahan ajar audio visual dan bahan ajar interaktif.

Adapun susunan isi LKPD biologi kelas XI IPA ialah dimulai dari judul sub bab, tujuan pembelajaran, alat dan bahan, gambar, langkah kerja, tabel data hasil pengamatan, dan bahan diskusi. Hal ini sesuai dengan teori yang diungkapkan oleh Prastowo (2015) yang menyatakan bahwa struktur Lembar Kerja terdiri atas enam komponen yaitu judul, petunjuk belajar, kompetensi dasar atau materi pokok, informasi pendukung, tugas atau langkah kerja dan penilaian. Dari beberapa teori diatas LKPD yang telah disusun sesuai bahwa LKPD termasuk bahan ajar, berdasarkan tata letak isi LKPD sudah sesuai urutannya, susunan kalimat mudah untuk dimengerti dan sudah terdapat gambar pada LKPD biologi kelas XI IPA.

Hasil analisis LKPD biologi disesuaikan dengan peraturan menteri pendidikan dan kebudayaan republik Indonesia nomor 8 Tahun 2016 tentang buku yang digunakan oleh satuan pendidikan pasal 3. Analisis bagian kulit buku yang dinilai yaitu kulit depan buku, kulit belakang buku, dan punggung buku. Pada bagian kulit buku diperoleh nilai 66,6\%, karena punggung buku tidak ada sehingga dapat disimpulkan bahwa bagian kulit buku masuk kategori cukup. Selanjutnya analisis pada bagian kedua yakni bagian awal buku mendapatkan nilai sebesar 0\%, adapun yang dianalisis ialah halaman judul, halaman penerbitan, halaman tabel, kata pengantar, daftar isi, dan daftar gambar. Nilai tersebut menunjukkan bahwa bagian awal buku termasuk kategori sangat kurang sehingga guru perlu untuk memperbaiki tampilan LKPD Biologi kelas XI.

Analisis LKPD biologi yang ketiga yaitu teknik penyajian. Pada teknik penyajian yang dinilai meliputi konsistensi sistematika sajian dalam bab, penomoran halaman, keruntutan dengan kompetensi inti dan kompetensi dasar, penyajian gambar pada setiap bab, penyajian tabel pada setiap bab, dan bahasa yang mudah dimengerti. Bagian ini memperoleh nilai 83,3\% karena LKPD ini kurang mencantumkan nomor halaman. Apabila dicantumkan halaman maka akan mempermudah juga dalam keterbacaan lembar kerja. Sehingga pada bagian teknik penyajian termasuk kategori sangat baik. Sedangkan pada bagian penutup mendapatkan nilai 
0\% karena glosarium dan daftar pustaka di LKPD tidak ada. Nilai 0\% mengartikan bahwa pada bagian penutup termasuk kategori sangat kurang. Apabila semua skor dijumlahkan dan ditotal maka mendapatkan nilai $37,5 \%$.

Jika disesuiakan dengan Permendikbud nomor 8 Tahun 2016 hasil analisis bagian penyajian ketika skor dijumlahkan semua maka memperoleh nilai 37,5\% maka artinya LKPD pada aspek penyajian masuk kategori kurang. Karena kurang memenuhi persyaratan yang sudah tertera pada pasal 3 ayat 1 yang berbunyi Kriteria Buku Teks Pelajaran maupun Buku Non Teks Pelajaran yang layak digunakan oleh Satuan Pendidikan yaitu wajib memenuhi unsur: kulit buku, bagian awal, bagian isi dan bagian akhir.

Analisis materi biologi kelas XI IPA terdapat sebelas bab pembahasan. Semester ganjil terdapat 6 bab sedangkan semester genap memperlajari 5 bab. Adapun hasil analisis berdasarkan materi pada lembar kerja biologi yang telah digunakan sebagi bahan ajar bahwa kompetensi dasar kurikulum 2013 matapelajaran biologi kelas XI IPA dan ringkasan materi tidak dicantumkan pada LKPD. Untuk mengetahui kompetensi dasar matapelajaran biologi dapat diketahui melalui tujuan pembelajaran yang telah tercantum pada LKPD biologi kelas XI IPA. Tujuan pembelajaran yang dicantumkan sesuai dengan kompetensi dasar matapelajaran biologi kelas XI IPA. Hilda Taba dalam Arifin (2014) mengatakan bahwa ketika guru memiliki inisiatif untuk mengembangkan kurikulum 2013 dengan membuat bahan ajar pribadi maka guru tersebut harus memahami aspek-aspek yang ada dalam komponen isi/materi kurikulum yaitu teori, konsep, generalisasi, prinsip, prosedur, fakta, istilah, contoh, dan definisi. Kriteria untuk memilih isi/materi kurikulum ialah materi harus shahih dan signifikan, artinya harus menggambarkan pengetahuan mutakhir. Materi harus relevan dengan kenyataan sosial dan kultural agar peserta didik lebih memahami fenomena dunia termasuk perubahan-perubahan yang terjadi. Materi harus mencakup tujuan. Materi harus sesuai dengan kemampuan dan pengalaman peserta didik. Dan materi harus sesuai dengan kebutuhan dan minat peserta didik.

Analisis aspek kebahasaan LKPD semester ganjil mendapatkan nilai dengan kategori sangat baik bab sistem sirkulasi, karena pada bab ini tidak ada kesalahan atau kekurangan. Sedangkan yang mendapatkan nilai terendah ialah bab jaringan hewan dengan kategori nilai cukup. Karena ada kesalahan penulisan ilmiah dibab tersebut. Adapun LKPD semester genap hampir semua bab mendapatkan nilai yang sama yaitu antara $80 \%$ dan $60 \%$. Artinya pada bab tersebut termasuk kategori baik dan cukup. Berdasarkan hal tersebut LKPD ini layak digunakan oleh siswa. Syarat menyusun LKS dalam susunan kalimat dan kata-kata diutamakan sederhana dan mudah dimengerti, singkat dan jelas, istilah baru hendaknya diperkanalkan terlebih dahulu (Nurdin, 2016). 


\section{KESIMPULAN DAN SARAN}

\section{Kesimpulan}

Kesimpulan penelitian ini yang pertama ialah pembelajaran biologi menggunakan LKPD di lembaga SMAN 3 Jember sesuai dengan tujuan penyusunan LKPD yaitu untuk meningkatkan keaktifan siswa di dalam proses belajar mengajar, membuat siswa berfikir kritis, membuat siswa rajin membaca dan pembelajaran menjadi inovatif. Bahan ajar tersebut bermanfaat untuk guru dan siswa. Bagi guru dapat digunakan sebagai pegangan proses pembelajaran berlangsung. Kedua yaitu kesesuaian antara LKPD dengan kurikulum 2013 pada penyusunan isi LKPD setelah dianalisis kurang sesuai dengan Permendikbud nomor 8 Tahun 2016 tentang buku teks dan non teks yang digunakan oleh satuan pendidikann. Masih terdapat beberapa kekurangan oleh karenanya LKPD ini perlu diperbaiki susunan isinya agar layak digunakan oleh siswa.

\section{Saran}

Setelah mengetahui keseluruhan isi LKPD setelah dianalisis maka yang perlu diperbaiki adalah penambahan halaman daftar isi, dan penambahan penomoran halaman disetiap sub bab LKPD agar siswa mudah untuk mencari sub bab yang akan dituju. Perlu adanya penambahan sub bab pada LKPD semester ganjil bab sistem regulasi dan sistem reproduksi. Karena masih ada KD yang belum tercantum di dalam LKPD biologi ini. Lebih baik diberikan tulisan bab untuk memisahkan setiap bab, serta Penambahan penulisan Kompetensi Dasar disetiap bab. Pada bagian akhir buku yaitu penambahan daftar pustaka.

\section{DAFTAR RUJUKAN}

Abdullah, Ridwan. 2018. Pembelajaran Saintifik untuk Implementasi Kurikulum 2013. Jakarta: Bumi aksara

Arikunto, Suharsimi. 2009. Manajemen Penelitian. Jakarta: Rineke Cipta.

Azmi, Nurul, Prastowo Puji, dan Maslena. 2017. Analisis kesesuaian lembar kerja Peserta Didik (LKPD) biologi kelas X yang digunakan MAN Rantauprapat Kabupaten Labuhan Batu. Vol.6. Medan: Jurnal Pelita pendidikan.

Huberman. M. B. Miles dan Johnny Saldana. 2014. Qualitative Data Analisis: A Methods Soursbook. California: SAGE Publication

Majid, Abdul. 2017. Strategi pembelajaran. Bandung: Remaja Rosda Karya.

Maryam, Siti dan Hidayati Sukarni. 2013. “Analisis isi lembar kegiatan siswa (LKS) biologi SMA yang digunakan dikota Yogyakarta”. Jurnal Pendidikan Matematika dan 
Sains Edisi I. https://www.academia.edu/15678996/Abstrak-penelitian-lks Diakses di web pada tanggal 15 Maret 2019.

Nurdin, Syafruddin. 2016. Kurikulum dan pembelajaran . Jakarta: Grafindo persada

Permendikbud No 37 Tahun 2018

Permendikbud No 8 Tahun 2016

Prastowo, Andi. 2015. Panduan Kreatif Membuat Bahan Ajar Inovatif. Yogyakarta: Diva Prees Sani. 